\title{
HOW DOES GOOGLE SEARCH EFFECT OUR INTELLIGENCE
}

\author{
Aansumol Yohannan \\ Keraleeya Samajam Dombivli's Model College, \\ Dombivli east, Mumbai, Maharashtra, India
}

\begin{abstract}
Google search provides a lot of information at our fingertips so it is nowadays the answer to most questions. As a result people are primed to think of it, when asked different questions, even when they know the correct answer or if the question is difficult and the answer is unknown. No longer we make efforts to search out the items we would like. We just "Google" our recent schoolmate, find articles online, or look up the actor who was on the tip of our tongue. But the question that arises is, does it affect our memory and attention span. Our growing dependence on the Internet has actually changed how and what our brain chooses to remember. So this study involves researching and analyzing data on how does google search effect us and our intelligence, the impact of it across society. And its influence it has on our brain structure and functioning remains a central topic of investigation. This study also addresses the key areas like its effect on the way students learn, its influence on our brain and the discussion of the google search and its effects among the public. Data from scientific studies was evaluated and used to draw conclusions about these effects where appropriate, and news articles and other media were looked at to provide a rational perspective on the topics in modern society.
\end{abstract}

Keywords-Google search, Brain Structure, intelligence, Google effect, Brain rewiring, Brain plasticity.

\section{INTRODUCTION}

Take a glance at this question: how does movies represent the characteristics of humanity?.If you were asked this question, what would your first step be in response to it?.Would you write down your thoughts- or would you like to Google it? Terry Heick, who was a former English teacher in Kentucky, had a really surprising revelation when his eighth- and ninthgrade students looked Google for the answer. What they did was they began Googling the question they was given to think upon and give their own views[Zhai Yun Tan et al.,2006]. This is a real eye opener to us. Similarly for those who grew up with search engines, particularly Google, at their fingertips looking at all of the people born in this Google era , this might seem intuitive. We grew up having our queries instantly answered as long as we have access to the net .This is called the Google effect, also called digital amnesia, it is the tendency to forget information that can be found readily available online by using Internet search engines[Betsy Sparrow, Jenny Liu, Daniel M. Wegner et.al., 2011]. According to the primary study regarding the Google impact individuals square measure less doubtless to recollect bound details they believe are accessible on-line. Now, with the arrival of assistants like Siri and Google currently that aim to cater data before you even grasp you wish it, you don't even need to type the questions. Just say the words and you may have your answer. But with most data simply on the market, will it build you smarter? How are those who grew up using the Internet that is the so-called Google generation different compared to the generations before who had to adapt to the internet. Heick had meant for his students to require a flash to assume, work out what variety of data they required, how to evaluate the data and how to reconcile conflicting viewpoints. He failed in it as his students instantly googled the question, word by word, eliminating the method of essential (critical) thinking[Zhai Yun Tan et al.,2006].

\section{LITERATURE REVIEW}

Writer Saint Nicholas Carr contends that the net can remove our ability for contemplation thanks to the malleability of our brains. He wrote regarding the topic during a 2008 article for The Atlantic titled "Is Google making us Stupid." what the Internet seems to be doing is chipping away our capacity for concentration and contemplation," said Carr[Nicolas Carr et al;,2008].A 2008 study commissioned by land Library found that youth undergo data online very quickly even without evaluating for its accuracy .A 2011 study in the journal Science Google Effects on Memory: Cognitive Consequences of Having Information at Our Fingertips showed when people know they will be having future access to information, they tend to have a better memory of how and where to find the needed information instead of recalling the information itself [Betsy Sparrow, Jenny Liu, Daniel M. Wegner et al., 2011]. That development is comparable to not basic cognitive process that you may forget your friend's birthday as a result that you know that you can find it on Facebook later. When we grasp that we are able to access this data whenever we would like, we are not motivated to remember it. The Internet is a universe rich in information; sometimes referred as the "information super highway". Often seems as one could find literally anything there, and indeed punching one's questions into Google would never ever disappoint us. Reviews of a recent bestseller, analysis of a chess game, the lately published microbiology studies, and a 


\section{International Journal of Engineering Applied Sciences and Technology, 2019 Vol. 4, Issue 8, ISSN No. 2455-2143, Pages 217-220 \\ Published Online December 2019 in IJEAST (http://www.ijeast.com)}

beginner's course on calculus are all available easily and quickly on the Internet, among many, many other things. So with all this information out there, one would imagine that the web would be an enormous boon to colleges, boosting test scores and the general level of knowledge among students around the world. However, unsurprisingly, there is also a huge amount of comics, games and music - things that the young people would would like to spend their time on than the school assignments. Friday's issue of the journal Science published findings does not prove that Google, Yahoo or other search engines are making us any dumber, as some have said.We're still capable of basic cognitive process things that matter and aren't simply found on-line, Sparrow said. Rather, it suggests that the human memory is reorganizing wherever it goes for knowledge, adapting to new computing technologies instead of relying strictly on committal to memory memory. We are outsourcing search from our brains to our computers. "We're not thoughtless frivolous folks that don't have recollections any longer," Sparrow said [Betsy Sparrow, Jenny Liu, Daniel M. Wegner et.al.,2011].Rather, it suggests that the human memory is reorganizing wherever it goes for data, adapting to new computing technologies rather than relying purely on rote memory. We have been outsourcing "search" from our brains to our computers. In a series of 4 experiments at Columbia and Harvard, Sparrow and her team found that students are more likely to recall a trivial fact if they think it will be erased from the pc and forget it if they're assured it'll be there. Similarly, the team proved that folks are higher at memory wherever to search out facts, rather than the facts themselves. The students found that they recalled the names of files where the information was stored, rather than the information itself. This creates a mental dependency on instant access to information, the team noted[Sparrow et al.,2011]. No surprise the loss of our net association looks like losing an addict, they wrote. Once we tend to become dependent on a large reservoir of data, it feels uneasy to be aloof from it, she said. "We should stay blocked in to understand what Google is aware of," the paper concludes. Proving that the web is just Associate in Nursing swollen network of individuals, ny University academician Clay Shirky, author of the book "Cognitive Surplus," has done the math: The articles, edits, and arguments on Wikipedia represent regarding one hundred million hours of human labor, he calculated. That's more than 11,400 years. If we tend to quit memory, "the net would grind to a halt," Sparrow said. "Nobody would be feeding anything into it" [[Betsy Sparrow, Jenny Liu, Daniel M. Wegner et al., 2011].There are losses in contrast to their great-grandparents, few of today's youngsters will recite poems .Perhaps this is often a skill that doesn't turns rusty. In an experiment, the researches has students write down in a text document on a computer 40 pieces of trivia and tested them in different ways. For the first group, students were either told their answers would be saved or that they would be erased. When asked later to write down as many statements as they could remember, those who thought their answers would be saved could not recall as many statements as those who thought their answers wouldn't be saved. In the last experiment, a group performed the same task as in the second experiment, but everyone was told their work would be saved in folders with labels, such as "info", "fact", etc. When asked to recall the statements they had written, students could only recall 1/4th of the statements. But if the researcher asked in which folder a specific statement had been saved, they were able to identify $1 / 2$ of the folders. This suggests that when presented with information, if we know where we can find this information again, we will remember where to find it, rather than the information itself. This provides real evidence for the Google Effect on memory, though it would be a rather large stretch to call it brain damage. Drawing attention to the internet's effect on our brain is essentially the same complaint that movies make kids less inclined to read. And they aren't wrong. People did stop carrying around a lifetime of accumulated facts in their heads, but they were also able to pass down what they had learned and discovered to later generations. This act of cultural inheritance is what made the world we live in today and why I even know who Socrates even is, a man who has been dead for a few thousand years. Which also means that the Internet's effect on our brain is real. Our brains will always rewire our synapses to make sense of the information it is receiving and so the new way of receiving information through the internet will effect our brain's structure. But this isn't brain damage, it's brain plasticity.

\section{METHODS AND MATERIALS}

This study primary data analysis study which allows to provide us a detailed interpretations of phenomena without depending on any numerical measurement; it's focus is on discovering the true inner meanings and new insights. It also refers to research information, collected as a result of studies and similar efforts that can be used by others either as a comparison data or as a part of the new research. Carried out a sample analysis using interview and observation.

\section{DATA \& RESULTS}

The first experiment ran was to determine what a person would do when presented with challenging questions. I asked a set of questions to a group of 30 people studying in a degree college for MSC IT they were randomly selected for testing. A questionnaire containing 10 questions was given, to them to answer.

Sample group size :- 30

\begin{tabular}{|c|c|c|}
\hline $\begin{array}{c}\text { Question:-Does movie } \\
\text { characters influence } \\
\text { us? }\end{array}$ & $\begin{array}{c}22 \text { out of 30 } \\
\text { instantly } \\
\text { googled it and } \\
\text { gave views }\end{array}$ & $\begin{array}{c}8 \text { scribbled down their } \\
\text { thoughts and gave } \\
\text { their opinions }\end{array}$ \\
\hline
\end{tabular}




\section{International Journal of Engineering Applied Sciences and Technology, 2019 \\ Vol. 4, Issue 8, ISSN No. 2455-2143, Pages 217-220 \\ Published Online December 2019 in IJEAST (http://www.ijeast.com)}

\begin{tabular}{|c|c|c|}
\hline $\begin{array}{l}10 \text { words were } \\
\text { displayed on screen } \\
\text { and was asked to } \\
\text { memorize(For this } \\
\text { experiment } 30 \text { people } \\
\text { were divided in to } \\
\text { group of } 15 \text { each) }\end{array}$ & $\begin{array}{c}\text { The first } \\
\text { group were } \\
\text { shown words } \\
\text { and asked to } \\
\text { memorize and } \\
\text { were } \\
\text { informed that } \\
\text { this words are } \\
\text { not stored } \\
\text { anywhere. } 11 \\
\text { out of } 15 \\
\text { remembered } \\
\text { the words } \\
\text { correctly. }\end{array}$ & $\begin{array}{l}\text { The second group } \\
\text { were told to do same } \\
\text { but were informed that } \\
\text { it is stored in the } \\
\text { computer resulted only } \\
4 \text { out of } 15 \\
\text { remembered it. }\end{array}$ \\
\hline $\begin{array}{l}\text { Played Game of dumb } \\
\text { charades }\end{array}$ & $\begin{array}{c}\text { After } 4 \\
\text { rounds, the } \\
\text { first group } \\
\text { referred to } \\
\text { google to look } \\
\text { for movie } \\
\text { names they } \\
\text { knew but } \\
\text { were unable } \\
\text { to recollect } \\
\end{array}$ & $\begin{array}{l}\text { The second group } \\
\text { googled the actor } \\
\text { name for even the } \\
\text { movies known to } \\
\text { them. }\end{array}$ \\
\hline $\begin{array}{l}\text { Asked them to listen to } \\
\text { music when they are } \\
\text { stressed for 10days }\end{array}$ & $\begin{array}{l}26 \text { out of } 30 \\
\text { confirmed } \\
\text { that they did } \\
\text { the same on } \\
11 \text { th day as } \\
\text { well }\end{array}$ & $\begin{array}{l}4 \text { of them did some } \\
\text { other activity }\end{array}$ \\
\hline
\end{tabular}

The first question asked shows that people are inclined to search in Google for even their opinion related questions .It resulted in stopping the process of critical thinking. There's an old saying in neuroscience: "Neurons that fire together wire together" [ Merzenich M et al.,2006 Growing evidence of brain plasticity].This means the more you run a neural-circuit in your brain, the stronger that circuit becomes. For example The more you practice piano, or speaking a language, or juggling, the stronger those circuits get. Thus we can say our brain has capacity to wire a new thought/habit with repetition In other words can reprogram our mind. The more consistently you wire in a new behaviour, action, thought, the more it becomes a part of your habit. The second experiment done shows that people remember information more when they are not sure that it is stored somewhere and if they are aware that they can access it later there are more chances to remember the place where it is stored than the information itself. The third experiment shows that people look google even for simplest things they are already aware of instead of trying to recollect/remember.Last activity proves the saying Neurons that fire together wire together the activity done for 10 days it become their habit, this shows even google search can also turn out as a habit which will effect us badly as it stops our thinking process[Reeves Christina et.al.,2018] .

This shows that, our brains are rewiring themselves to adapt to the Internet age. Experiment shows increasing tendency of people to use google. This also proves the increasing dependency of people on google search. Thus not using their ability of critical thinking.

\section{DISCUSSIONS}

Even if some consider that as a form of brain damage, and some don't, it isn't exclusive to the internet. People get addicted to all sorts of things for all sorts of reasons.

What's more is that, the increased dependency on Internet effect on our brain it doesn't acquire information from other sources. It also at times provides us inadequate information.

In order evrything.to keep Google updated we humans need to gain information and it won't be able if we keep searching google itself for everything. As it will become our habit and it can be dangerous. Google itself is repository of information by people. So if we stop our critical thinking and research in other mediums at a certain point even google information ill become stagnant. The Internet's effect on our brain makes it more likely that we'll fail to recognize our vulnerability.

And there isn't even space here to begin discussing the issues of what has happened to our privacy in the Internet era and the effect that is having on our psychological well-being. The Google search is effecting society by rewiring the people's way of finding information and thinking. It's also restructuring our brain and its functioning. Even students, the future generation also refers to it for questions asked to know their views which is bit shocking.

\section{CONCLUSIONS}

Change is Never Easy, But it's the Least of our Problems. It goes without saying that we'll always have problems, but Google's effect on our memory, and the Internet's effect on our brain may have real implications for our future. While this should be discussed, people are not considering it as a issue. With the considerable of people to google search it is necessary for them to understand its effect on our memory and our intelligence. Of course google has been a boon which provides us with lot of information. But it is necessary to use it accordingly. As of October 2018, Google processed about 10.34 billion explicit core search request. There are 5.8 billion total daily searches on average or 71,780 searches per second as per a report. This shows increasing dependency on google search. The following things needed to be done. 
Use more of our critical thinking and form your opinions rather than just doing google search for every question asked

Google is a repository which gets information from intellectual people itself so start gaining information from other mediums too otherwise there will come a time when google information may get stagnant

Our Brain has capacity to rewire itself so don't make it a habit to google search everything.

\section{ACKNOWLEDGMENT}

First of all, I would like to thank the Almighty God and With due respect and gratitude I take this opportunity to thank all those who have helped me directly and indirectly. I express my sincere gratitude towards co-operative department who have provided me with valuable assistance and requirements for the research and all the publishers of the cited journals . I would like to take this opportunity to thank our Professors for giving all the help and guidance I needed. I am also grateful to our Head of Department . This acknowledgement will remain incomplete if we do not mention sense of gratitude towards our esteemed Principal who provided us with the necessary guidance, encouragement and all the facility available to work on this project.

\section{REFERENCES}

1. https://www.npr.org/sections/alltechconsidered/2016/ 02/05/465699380/ok-google-where-did-i-put-mythinking-cap.

2. Nicholas Carr July/August 2008 The Atlantic Magazine :- Is Google-making us stupid published.

3. Betsy Sparrow, Jenny Liu, Daniel M. Wegner 2011 Google Effects on Memory: Cognitive Consequences of Having Information at Our Fingertips DOI: 10.1126/science.1207745by published.

4. TED talks: Growing effects of brain plasticity.

5. Zhai Yun Tan 2016 OK, Google, Where Did I Put My Thinking Cap?

6. Merzenich M et al.,2006 Growing evidence of brain plasticity

7. Christina Reeves, 2018,Neurons that fire together wire together.

8. https://bluelist.co/blog/how-many-googlesearches-per-day/ 